\title{
Hair fiber characteristics and methods to evaluate hair physical and mechanical properties
}

\author{
Maria Valéria Robles Velascoㅁ, Tania Cristina de Sá Diass ${ }^{1}$, Anderson Zanardi de Freitas ${ }^{2}$, \\ Nilson Dias Vieira Júnior², Claudinéia Aparecida Sales de Oliveira Pinto ${ }^{1}$, \\ Telma Mary Kaneko', André Rolim Baby ${ }^{1 *}$
}

\author{
${ }^{1}$ Department of Pharmacy, School of Pharmaceutical Sciences, University of São Paulo, ${ }^{2}$ Lasers and Application Center, \\ Institute of Energetic and Nuclear Researches/IPEN-CNEN
}

\begin{abstract}
The hair thread is a natural fiber formed by keratin, a protein containing high concentration of sulfur coming from the amino acid cystine. The main physical proprieties of the hair depend mostly on its geometry; the physical and mechanical properties of hair involve characteristics to improve: elasticity, smoothness, volume, shine, and softness due to both the significant adherence of the cuticle scales and the movement control (malleability), as well as the easiness of combing, since they reduce the fibers static electricity. The evaluation of these effects on hair may be carried out by several methods, as: optical and electron microscopy, mechanical resistance measuring, shine evaluation and optical coherence tomography (OCT).
\end{abstract}

Uniterms: Hair/properties/evaluation. Hair fibers/properties/evaluation. Hair fibers/characteristics. Optical coherence tomography/analytical application. Optical microscopy/analytical application. Electron microscopy/analytical application

\begin{abstract}
O cabelo é uma fibra natural formada por queratina, uma proteína composta por teor elevado de enxofre proveniente da cistina. As propriedades principais do cabelo dependem de sua geometria, estrutura física. Características físicas e mecânicas das fibras capilares envolvem propriedades que melhoram: elasticidade, maciez, volume, maleabilidade, facilidade para o ato de pentear e brilho. A avaliação de tais propriedades do cabelo pode ser obtida por métodos diversos, como: microscopia óptica e eletrônica, mensuração da resistência mecânica, determinação do brilho e tomografia por coerência óptica (OCT).
\end{abstract}

Unitermos: Cabelo/propriedades/avaliação. Fibras capilares/propriedades/avaliação. Fibras capilares/ características. Tomografia por coerência óptica/aplicação analítica. Microscopia óptica/aplicação analítica. Microscopia eletrônica/aplicação analítica.

\section{INTRODUCTION}

Hair threads form a major part of the external coating of most mammals. In the human being, hair represents a structure which long time ago lost their functional significance during the species evolution process. The value of the hair, however, should not be underestimated in emotional and social terms.

The hair thread has a cylindrical structure, highly organized, formed by inert cells, most of them keratinized

\footnotetext{
"Correspondence: A. R. Baby. Laboratory of Cosmetology, Department of Pharmacy, School of Pharmaceutical Sciences, University of São Paulo, Av. Prof. Lineu Prestes, 580 Bl. 13/15 - Cidade Universitária - 05508-900 - São Paulo - SP, Brazil. E-mail: andrerb@usp.br
}

and distributed following a very precise and pre-defined design. Hair forms a very rigid structure in the molecular level, which is able to offer the thread both flexibility and mechanical resistance. Hair is considered as a dead mater and it is only alive when it is inserted in the scalp (pilose follicle). When the thread emerges, it becomes dead matter although it appears to be growing since the fiber follows increasing its length by a speed of about $1.0 \mathrm{~cm} / \mathrm{month}$ (Cade, 1995; Dias, 2004; Longo et al., 2006).

Human hair has about $65-95 \%$ of its weight in proteins, more $32 \%$ of water, lipid pigments and other components. Chemically, about $80 \%$ of human hair is formed by a protein known as keratin (Kaplin et al., 1982; Wagner, Joekes, 2005), with a high grade of sulfur 
- coming from the amino acid cystine - which is the characteristic to distinguish it from other proteins. Keratin is a laminated complex formed by different structures, which gives the hair strength, flexibility, durability, and functionality.

Threads present remarkable structural differences, according to the ethnic group, and within the same group. These properties are related with fibers characteristics and with cosmetic attributes (Dias et al., 2007).

Among the first ones we have: resistance, elasticity, diameter, bending, color and shape of the cross section. In spite of depending on threads characteristics and on the morphological components integrity, cosmetic properties are: shine, combing, volume, malleability, retention of styling, and ability of flying away.

Hair has a particular genetic nature. We may handle it and applying on it products to mimic differences of the touch sensorial characteristics; these are, however, transient effects (Juez, Gimier, 1983; Dias, 2004).

\section{ANATOMY AND PHYSIOLOGY OF HAIR FIBER}

Hair fiber is composed by three main structures: cuticle, cortex and medulla. The main factor to be considered in the human hair is the high amount of the amino acid cystine, which may be degraded and afterwards may be re-oxidated under a disulphidic bounding form. This is the basis for the permanent curling process. Cystine is very stable; this is the reason why human hair may be found relatively intact, even after several years after the death of an individual.

Proteins with $\alpha$-helix structure wind each other by their left side, as if they were two stretched ropes (winded to each other, curled). When the hair is stretched, this curl gives it a kind of elasticity. Proteins which are winded in the hair have long filaments of unknown microfibers which link to each other to form bigger structures, in order to produce cortex cells. This enchained structure offers the capillary fiber more strength and elasticity (Wilkinson, Moore, 1990; Robbins, 1994; Wagner, Joekes, 2005).

\section{Cuticle}

The cuticle covers the hair thread from the scalp to the end as overlapping layer and it is the most important component of the human hair, since it may be more or less affected by cosmetic treatments. On the cuticle, cosmetic products, such as conditioners, hair sprays, mousses and gels are deposited. Dyers, straightening and curling products also spread themselves through the cuticle to expand their effects by the hair fiber. There are approximately 8 to 11 layers of cuticle, which are overlapped in the distal direction of the thread, depending on the type, condition, and length of the hair. Each layer is formed by only one cell. Each cell of the cuticle has a rectangular shape and they overlap in such way, that only 1/6 of them are exposed (Wilkinson, Moore, 1990; Robbins, Crawford, 1991).

Each cell of the cuticle contains a thin external membrane, the epicuticle $(\sim 3 \mathrm{~nm})$, which is a protein coat covered by a strong lipid structure. The other layers are:

- Layer A: a resistant structure containing cystine $(>30 \%)$. The cross links of proteins, in this layer, not only give physical resistance but also makes them relatively resistant to chemical attack. These properties protect the fiber against both mechanical and chemical attacks.

- Exocuticle: also known as Layer B, corresponds to $55 \%$ of the cuticle area and it is rich in cystine $(\sim 15 \%)$, and it is physically rigid (but less intensively than Layer A).

- $\quad$ Endocuticle: with low grade of cystine $(\sim 3 \%)$, this inferior part of the membrane is also considered as epicuticle. It is much softer than the superior layers and there are evidences that it swells with water. When the cuticle is wet, its rigid layers become quilted with alternate consecutive soft (as gel) and hard layers. This process also intensifies the apex of the surface stages of the thread, which also explains that the friction coefficient is higher in the wet hair than in the dry one. When the endocuticle is swelled it has a more brittle structure, which explains both breakage and scaling of threads if they are combed when they are still wet.

- Cellular membrane complex (CMC): these cells, with constant thickness $(30 \mathrm{~nm})$, separate all the cells in the cuticle. The 18-methyl eicosanoic acid (18-MEA) is one of the very important lipid components of the CMC. This lipid is also bound in a covalent way to the hair external surface. 18-MEA is the main lipid in the hair composition contributing to the wet and dry combing proprieties.

- Epicuticle: this is considered the most important part of the cuticle, from the polymers deposition point of view and it is the most external layer. The lipid bond (18-MEA) to protein matrix gives the cuticle a substantive hydrophobic surface.

The epicuticle represents a residual of the cuticle cells membrane and has a proteic nature. It is composed by about $25 \%$ lipids and $75 \%$ proteins, with $12 \%$ of 
cystine, which represents a high content of sulfur. The protein matrix is directed to the hair fiber surface and it is abundant in cysteil groups, near the surface, which are acidulated by fat acids (lipids) (Juez, Gimier, 1983; Robbins, 1994; Ruetch, Weigmann, 1996; Swift, 1999). Those lipids, involving mainly the 18-methyl eicosanoic acid (about $30 \AA$, or $3 \mathrm{~nm}$ ), form a hydrophobic region

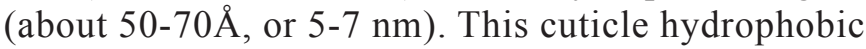
aspect is important because hydrophobic materials as silicones, fat alcohols, oils and polymers have great affinity for hydrophobic surfaces and they will not settle on hydrophilic surfaces. As the cuticle surface undergoes abrasion during the washing and drying processes, as well as in the combing, this hydrophobic layer is removed by washing the surface of Layer A. Layer A and their following layers may be oxidized to more hydrophilic layers. The condition of the cuticle is responsible for the hair visual and tactile properties, it has the potential to assist in diagnosis of health disorders and may also be used forensically to provide information on the identity of the hair's owner (Juez, Gimier, 1983; Robbins, 1994; Ruetch, Weigmann, 1996; Swift, 1999; Gurden et al., 2004).

\section{Cortex}

The cortex occupies most of the hair area $(75 \%)$. In the same way as the cuticle, it has cells filled by cross links of cystine and hard cells separated by the cell membrane complex (CMC). Each one of the cortex cells has a spindle shape, with a 50-100 $\mu \mathrm{m}$ length and a $3 \mu \mathrm{m}$ diameter. Each cell distal surface is rough, irregular, and they tie crossly to each other (Wilkinson, Moore, 1990; Robbins, Crawford, 1991; Robbins, 1994; Schlake, 2007).

\section{Medulla}

The medulla is a thin cylindrical layer in the center of the hair thread containing high lipid rate concentration and poor cystine. Its function is not yet completely elucidated, although its cells may become dehydrated and its spaces may be filled with air, which affects both color and shine in white brown and blond hair. The medulla has a small effect on most of the aspects of cosmetic hair treatments and they are only present in terminal hairs (Robbins, 1994; Cade, 1995; Oliveira, 2000). Recently, Wagner et al. (2007) studied the medulla using electron microscopy and observed that medulla presents three distinct subunits (globular structures, unorganized cortical cells and smooth covering layer), and also, two kinds of medulla were identified: thin and thick.

\section{PHYSICAL AND MECHANICAL PROPERTIES OF THE HAIR FIBERS}

\section{Hair physical proprieties}

Physical proprieties of hair depend mostly on its geometry. Caucasian hair is oval; Asian hair is circular; Afro hair is elliptic. Several mechanical proprieties are directly related with fibers diameter (Kolar, Miller, 1972; Juez, Gimier, 1983; Robbins, Crawford, 1991; Dias et al., 2005).

\section{Hair mechanical proprieties}

Hair is surprisingly strong. Cortex keratin is responsible for this propriety and its long chains are compressed to form a regular structure which, besides being strong, is flexible (Dias, 2004; Robbins, 1994). The physical proprieties of hair involve: resistance to stretching, elasticity and hydrophilic power.

\section{Resistance to stretching}

In general, the weight needed to produce a natural hair thread rupture is $50-100 \mathrm{~g}$. An average head has about 120,000 threads of hair and would support about 12 tons. The resistance to breakage is a function of the diameter of the thread, of the cortex condition, and it is negatively affected by chemical treatments.

When a certain load is applied on a hair and its elongation is measured we obtain the graphic representation of its several characteristic regions:

- Hookean's region or pre-recovering: during the stretching between 0 and $2 \%$ the elongation is proportional to the load applied.

- Recovering region: between $25-30 \%$ of stretching, the elongation considerably increases without a relationship with the load applied.

- After-recovering region: from 30\% stretching load and fiber extension are proportional again.

We may consider that in the first and third zones hair acts as a crystal solid; in the second, as an amorphous solid or a fluid since the fiber presents a plastic-type response. The changes underwent by hair during the stretching may be explained by the protein conversion and the possible conversion of $\alpha$-keratin with an organized and compact helicoid disposition to $\beta$-keratin with loose peptide chains.

The starting stage is known as Hookean's region. The hair structures consist of stable $\alpha$-keratin chains with hydrogen bonds and the hair thread seems a crystal solid. The slope of the curb over the elastic region depends on 
the $\alpha$-keratin cohesion, and all the factors affecting cohesion will decrease this value. Polypeptides are products of the amino acids chain and they are 18 in the human hair. In steady state, not stretched, polypeptide chains present helicoid structure which generates several bonds. The cystine-S-S bond is the strongest one and it occurs each 4 cycles of the spiral (Woodruff, 2002).

Hydrogen bonds with $\mathrm{C}=\mathrm{O}$ and $\mathrm{H}-\mathrm{N}$ groups occur in almost every cycle. Therefore, in the Hookean's region (the elastic region) interference occurs coming from the $\alpha$-keratin form as stretching resistance, by hydrogen bonds which stabilize the helicoid structure (Juez, Gimier, 1983; Woodruff, 2002).

In the non-Hookean's region the transition of $\alpha$-keratin to $\beta$-keratin occurs, when a peptide chains displacement appears without a high degree of resistance. The third stage, the post non-Hookean's region is related with the resistance of the $\beta$-keratin configuration to stretching, until reaching the rupture point.

The analysis of the load-elongation curb of threads helps to recognize hair behavior, when several procedures are applied for styling hair. The application of products with reducing character, a process of straightening (Dias et al., 2005; Dias et al., 2008) or waving of reducing and oxidant type or a process of hair discoloration, change the shape of the load-elongation curb. The first and second zones become more extensive; on the other hand, the value of the needed load for starting the transition in the first and second regions of the curb is decreased (Kolar, Miller, 1972; Juez, Gimier, 1983; Wilkinson, Moore, 1990; Tate et al., 1993; Robbins, 1994; Feughelman, 1997; Ishii, 1997; Woodruff, 2002).

\section{Hair elasticity}

Hair fiber has an elastic characteristic, and it may undergo moderate stretching either wet or dry. Stretching is a hair attribute under the action of a distal force (length) and the thread returns to the original status, when this force stops acting. When dry, the hair thread may stretch 20-30\% of its length; and, in contact with water, this may reach up to $50 \%$. In contact with ammonia it becomes more elastic. Chemical and physical treatments, sun exposition and use of electric dryers and heated plates affect this propriety (Juez, Gimier, 1983).

\section{Hydrophilic power}

Hair absorbs water under both liquid and steam form. Keratin may absorb up to $40 \%$ of its own weight in water. Hydration is favored by temperature increase, by changing $\mathrm{pH}$ and by all the polar solvents which break hydrogen bonds. Hydration changes the fiber elasticity.

Keratin has special affinity for water. This absorption depends on the air relative humidity rate and greatly interferes on all the proprieties of the hair, as: stretching ability, diameter and internal viscosity of the fibers (Juez, Gimier, 1983; Robbins, 1994).

Hair tends also to be pervious to water in its liquid form. This absorption is followed by a swelling in the hair, with $15-10 \%$ increase in its thread diameter and $0.5-1.0 \%$ in its length. Both absorption and swelling essentially depend on the mean $\mathrm{pH}$. Generally, swelling is favored by alkaline $\mathrm{pH}$. Other polar solvents as urea solutions, acetamide and lithium bromide have a similar effect on hair threads.

Normally, the hair resistance to swelling is due to the existence of bonds maintaining the reticular integrity, which avoids the molecules penetration in a volume which is superior to the existing one between protein chains.

This absorptive and swelling phenomenon in the fiber may be of great application in hair care products, because it allows a favored or delayed penetration of certain organic molecules (Juez, Gimier, 1983; Robbins, 1994; Feughelman, 1997; Ishii, 1997).

\section{Surface properties of hair}

The hair existing in the normal scalp represents a huge surface, if we consider a mean value of $20 \mathrm{~cm}$ long for a thread with an $80 \mu \mathrm{m}$ diameter. Surface conditions are different as a function of the individual, hair type and length of each thread.

\section{Hair surface porosity}

When the hair is porous, chemical treatments as dyeing and straightening occur more rapidly.

Some situation influence on porosity:

- Alkaline $\mathrm{pH}$ over 8 increases permeability.

- High temperature accelerates water penetration.

- Chemical processes as permanent waving, discoloration, straightening and dyeing affects the porosity.

- Air relative humidity (Juez, Gimier, 1983; Robbins, 1994; Feughelman, 1997).

\section{Absorption}

Hair surface retains the thread natural oils (sebum) composed by tensoactive ingredients and some dyers. Absorption of fatty substances is due to a physical process of surface tension. The sebum absorption over the hair 
occurs by contact with the scalp and transference from a thread to each other. Chemical treatments enhance the surface anionic nature of the hair thread, which becomes electronegative, causing its physical-chemical affinity with cationic components, as tensoactive and dyeing ingredients (Juez, Gimier, 1983; Robbins, Crawford, 1991; Feughelman, 1997).

\section{Friction}

Friction is the force resisting the movement when a body slides over another one. The cuticle surface has high friction coefficient due to its scale shape and it depends on the cuticle geometry and on the physical-chemical status of the hair. The continuous attrition of a thread over another one damages the cuticle.

From the roots to the extremities the friction coefficient differs in the dry and wet hair thread, and it is enough combing to damage the hair. Several factors influence the friction, such as:

- relative humidity: friction is higher in wet than in dry hair.

- discoloration of the hair: discoloration increases the friction among threads.

- permanent waving and straightening: due to the chemical composition and high $\mathrm{pH}$ of ingredients the friction is increased (Dias et al., 2005; Dias et al., 2008).

- shampooing: the more is the detergent power the higher is the friction. The addition of conditioning substances promotes a lower friction coefficient than the one brought by the shampoo, without these substances.

Conditioning cream, rinse cream, bath of cream and related products reduce the friction among hair threads (Juez, Gimier, 1983; Robbins, 1994; Cade, 1995; Feughelman, 1997; Paula, 2001).

\section{Static load}

When a comb slides over the hair, surface electric load is generated by both friction and high electric resistance of the hair, which makes handling difficult. The static load dispersion is a function of fibers conductivity or electric resistance. Quaternary ammonium salts of long chain increase conductivity on the thread surface and reduce the friction.

The load potential depends on some factors:

- status of the hair surface, because the presence of an oily layer coming from the sebum or from a cosmetic product influences the static electricity effect, which is reduced or disappears.

- $\quad$ grade of humidity of the hair - thread electric loads tend to flow easier on wet than on dry hair, due to the lower electric resistance. As a consequence, the hair tends to become more 'electric' (fly away) in a dry environment than in a humid one (Juez, Gimier, 1983; Robbins, 1991; Feughelman, 1997; Ishii, 1997).

In an electric load test developed by Syed et al. (1995), it was observed that Afro-ethnic hair develops a high negative static load $(-25 \mathrm{kV} / \mathrm{m})$. On the other hand, Caucasian hair develops a very low positive electrostatic load $(+6.6 \mathrm{kV} / \mathrm{m})$. The high negative load acquired by dry Afro-ethnic hair being combed, may be due to the high traction force needed for passing the comb through tangled hair threads.

The act of combing chemically straightened Afroethnic hair results in a positive electrostatic load $(+25.9$ $\mathrm{kV} / \mathrm{m}$ ); this could be attributed to the easier combing and to the tangling of a minimum of hair threads.

If the Afro-ethnic hair is not chemically treated or straightened, it develops an electrostatic load significantly higher than the Caucasian hair. Relatively high electrostatic loads may provoke threads bristling (Syed et al., 1996; Dias, 2004).

\section{Isoelectric point}

Hair surface presents both positive and negative electric loads while the cuticle has an electrically neuter point (equals to the amount of positive and negative loads) under a pH 3.8 (isoelectric point). When the hair is left in contact with products whose $\mathrm{pH}$ value is over 3.8 it becomes more negative, since the $\mathrm{NH}_{3}^{+}$group loses its load. However, in $\mathrm{pH}$ values under 3.8 the hair becomes more positive, carboxyl groups are protoned and neutralized, and a predominance of the $\mathrm{NH}_{3}^{+}$group occurs (Juez, Gimier, 1983; Robbins, 1994).

\section{Shine}

Shine is one of the most important and desired cosmetic attributes of the hair. From the physical point of view, it is related with the way by which the hair reflects and diffuses the incident light beam.

Thus, any factor which changes light reflection would have influence on shine. Since this is a surface propriety, cuticle is the main responsible by it. Damages on cuticle (opening and breakage of scales), as well as 
dust particles and scalp secretions built up over threads reduce the shine. The increase of curls bending reduces its visualization and darker hair seems to be more brilliant than the light ones.

When a light beam reaches the hair surface, a part of it is reflected, another part is absorbed, and a third part is dispersed. The amount of light corresponding to each of these phenomena depends on the surface geometry, on the refraction index of the thread, and on the light incidence angle.

Factors influencing the shine perception, by order of importance are: reflection, light dispersion, alignment, and color.

These present favorable effect of hair shine:

- $\quad$ continuous and thin film over the scales;

- $\quad$ film with high refraction index;

- $\quad$ reflection being higher than diffuse dispersion.

These present unfavorable effects:

- $\quad$ higher light dispersion;

- film coating - irregular or discontinuous - over threads;

- $\quad$ chemical treatments as permanent waving and discoloration, which cause changes on the flat positioning of the cuticle due to the scales lifting (Reimer et al., 1995; Ishii, 1997; Starch, 1999; Schueller, Romanowski, 2001).

\section{Combability}

Combability may be defined as the subjective perception of the easy or difficult way for combing the hair. It is directly related with the forces which are opposite to the action of combing the hair. This is an important attribute in the evaluation of the hair conditioning (Dias et al., 2005; Dias et al., 2008). For the consumer, a better combability reflects a better hair conditioning.

Other factors related with combability involve malleability and mechanical damages - which may occur when we normally comb the hair, and they are worsened when we detangle it (Garcia, Diaz, 1976; Syed et al., 1996; Ishii, 1997).

\section{METHODS TO EVALUATE HAIR PRODUCTS}

The desire for products that improve the look and feel of hair has created a huge industry for hair care. Characterization of the structure and physical and mechanical properties of hair are essential to develop better cosmetic products and advance Biological and Cosmetic Science (Bhushan, Chen, 2006). The evaluation of hair products efficacy may involve the use of devices which generally have high sensitivity. These tests are specific and only provide information on one attribute for assay. Normally, equipment is used to obtain the image, which is assessed in a subjective way. Analyses performed on pre-defined regions of hair locks in order to standardize the method and to have more reliable results.

The advantages of these techniques, when compared with merely subjective evaluations are:

- $\quad$ there is not the need of a volunteers panel;

- $\quad$ some evaluations may be rapidly performed;

- use of specific hair locks;

- condition of standardized assay;

- $\quad$ they may be used for complex studies.

Some of the most used methods for evaluating hair products are listed below.

\section{Scanning Electron Microscopy (SEM)}

The scanning electron microscopy (SEM) is very used for analyzing hair threads. This technique allows observations of thick and not transparent samples under an electron beam. It also allows determining the shape of a material, the size of its component particles, and its layout (Dias, 2004). The Figure 1 illustrates a photomicrograph of an Afro-ethnic hair sample obtained by SEM.

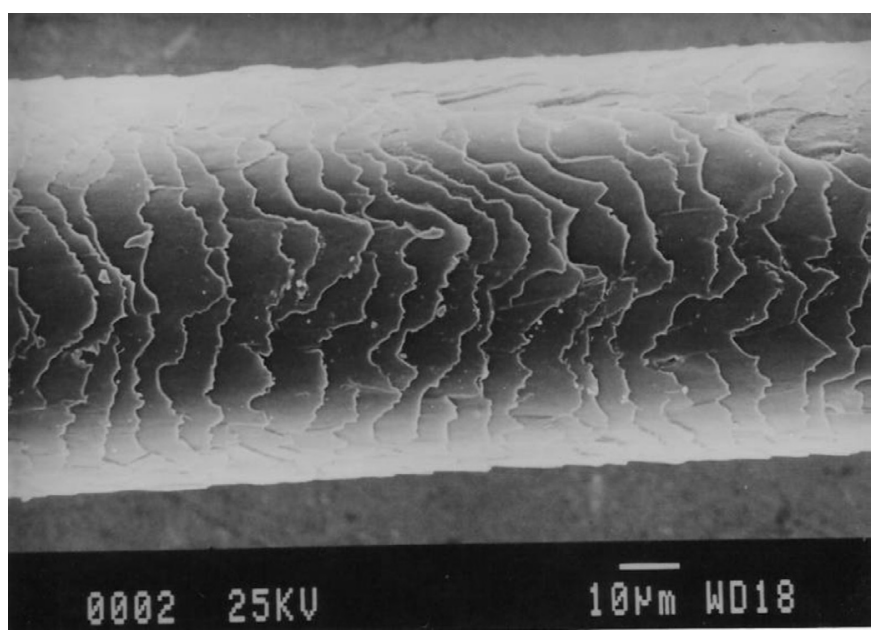

FIGURE 1 - SEM photomicrograph of an Afro-Ethnic hair sample.

SEM is very used for big magnification of a given sample, generally to evaluate hair surface morphological conditions. The sample is coated with a carbon/gold film in order to lead electric current; then, under high vacuum, an electron beam is directed over it and the scattering is assessed by a detector, thus the image is generated. 


\section{Atomic force microscopy (AFM)}

This equipment allows observing sample images through the microscope, in environment conditions or even when we have a solution. The image is captured by a probe which has physical contact with the sample, and follows a parallel plan to the surface while acquires each point of the topographic component. The probe deflection is then measured by a computer program (software) which generates the image.

Through this equipment it is also possible to have quantitative data on electric loads distribution and sensor force to travel the sample (Smith, 1997; Dias, 2004).

\section{Mechanical assays}

The hair, when considered as a physical body, is a very resistant fiber. The rupture load of a healthy hair thread ranges from 50 to $100 \mathrm{~g}$. The relative value is directly proportional to the thread length. To perform this assay a dynamometer is used - this is equipment frequently used for evaluating: hair rupture tension, elasticity, combability and detangling. The device exerts a tension on the hair thread and measures the needed force versus elongation. The hair lock is tied with a support, and then two combs pass through it as well as the needed force for this action (Syed et al., 1996; Ishii, 1997; Dias, 2004).

\section{Piezoelectric sensors}

This analysis is very close to the sensorial perception. The piezoelectric principle is based on the deformation of a crystal by a mechanical action. When this occurs, a load displacement is induced - so creating a voltage signal. In hair, it is possible applying this technique to the tactile perceptions of hair proprieties, as: conditioning, cleanliness and surface roughness. During the evaluation, the sensor is placed on a mechanical arm which touches the hair lock and afterwards it is released. This is repeated several times. Results are expressed as voltage arbitrary values (Reimer et al., 1995; Ishii, 1997; Schueller, Romanowski, 2001).

\section{Glossmeters}

Glossmeter is a piece of equipment designed to measure the hair shine. The regularity of the hair surface helps to determine the light reflection. When the light follows a uniform surface, as in a mirror, the incidence angle is exactly equals to the reflection angle. However the hair is not totally uniform and at some points the light beam is reflected forming different angles $\left(0\right.$ to $\left.75^{\circ}\right)$ and this kind of reflectance is known as diffuse reflectance (Reimer et al., 1995; Ishii, 1997; Schueller, Romanowski, 2001; Dias, 2004).

\section{Subjective tests}

This kind of test aims to have a response through a trained panel or a specialized technician, or a group of trained volunteers' subjective assessment, after their evaluation of a test-product, in a way to mimic the final consumers' opinion. These assays allow non-parametric results and the protocols used in them search after standardizing some procedures in order to extrapolate a small group opinion to the target public. The main tests are: salon test and test under normal use conditions (Postiaux, 2000).

\section{Optical Coherence Tomography}

Optical coherence tomography (OCT) is a diagnostic imaging technology based on low length coherence interferometry in which the coherence features of photons are exploited, leading to an imaging technology that is capable of producing non-contact, non-destructive (Freitas et al., 2008), high-resolution cross-sectional images of the internal microstructure of living tissue such as: retina, skin (Huang et al., 1991) and teeth (Freitas et al., 2006). Its applications in medicine were reported less than a decade ago, but its roots lie in early works on white-light interferometry (Takada, 1987; Youngquist, Carr, Davies, 1987). The OCT image is based mainly in an optical property of sample, the backscattering coefficient. The false color in the image represents the backscattering coefficient, where white color represents high scattering and black color low scattering.

Figure 2(a) shows for the first time, with the best of our knowledge, the cross-sectional image of Afro-Ethnic hair, where is possible to identify the main hair structures: medulla, cortex and cuticle (Freitas et al., 2008). The mean diameter of medulla was $29 \pm 7 \mu \mathrm{m}$ and hair diameter was $122 \pm 16 \mu \mathrm{m}$ in our samples. The tridimensional image (Figure 2(b) was built starting from 601 cross-sectional images (slices) like Figure 2(a). Each slice was taken in steps of $6.0 \mu \mathrm{m}$ at 8 frames per second, and the whole 3D image was built in 60 seconds.

Figure 3 shows an OCT scan for Afro-ethnic hair, where we can see its main structures. The first peak corresponds to the cuticle, the valley corresponds to the cortex presenting lower scattering coefficient in relation to medulla and the two another peaks corresponds to the medulla. 


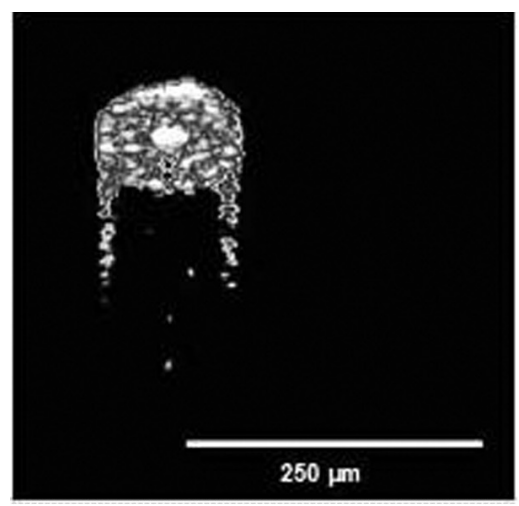

a)

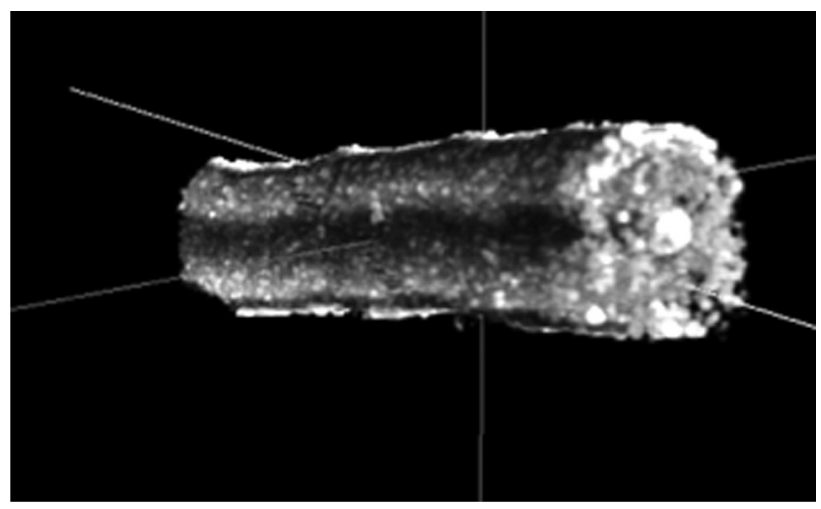

b)

FIGURE 2 - OCT image of an Afro-Ethnic hair sample. In (a) a sample of cross-section fiber and at (b) a tridimensional reconstruction of that fiber, showing the main hair structures: medulla, cortex and cuticle.

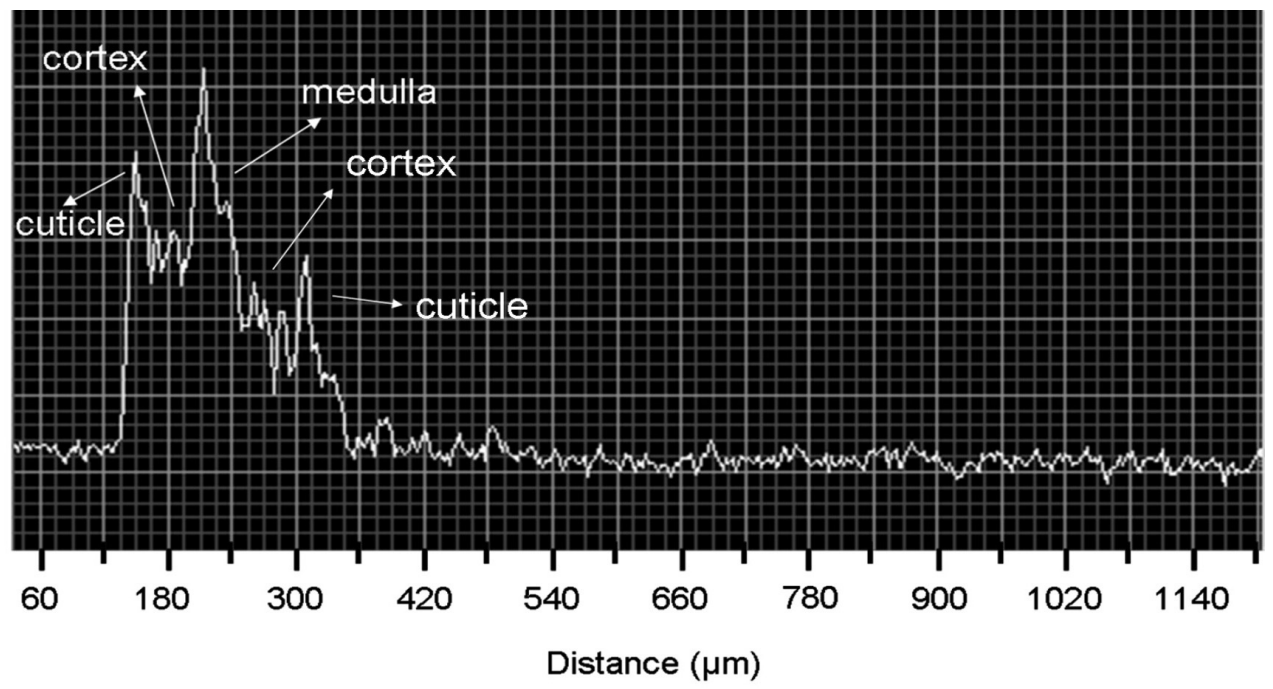

FIGURE 3 - Signal OCT profile for Afro-ethnic hair, showing the main structures.

Analyzing these images allows to compare backscattering coefficients of different structures presents in hair, and still to compare these coefficients before and after some chemical treatment, with the advantage of these technique to be non destructive, allowing to tracking the same fiber during whole the treatment process.

\section{ACKNOWLEDGEMENTS}

This work was supported by National Council for Scientific and Technological Development (CNPq), foundation linked to the Ministry of Science and Technology (MCT), to support Brazilian research, CAPES, FAPESP and Dow Corning. We are also grateful to the reviewers of this research work for their suggestions, contributions and kindly help.

\section{REFERENCES}

BHUSHAN, B.; CHEN, N. AFM studies of environmental effects on nanomechanical properties and cellular structure of human hair. Ultramicroscopy, Amsterdam, v.106, n.8-9, p.755-764, 2006.

CADE, P. Chemical hair straighteners, waves and treatment products. Edison: Croda, 1995. p.1-21.

DIAS, T. C. S. Análise da ação condicionadora de substâncias cosméticas adicionadas em alisante capilar à base de tioglicolato de amônio. São Paulo, 2004. 106p. [Dissertação de Mestrado. Faculdade de Ciências Farmacêuticas. Universidade de São Paulo]. 
DIAS, T.C.S; BABY, A.R; KANEKO, T.M.; VELASCO, M.V.R. Protective effect of conditioning agents on Afroethnic hair chemically treated with thioglycolate-based straightening emulsion. J. Cosmet. Dermatol., Oxford, v.7, n.2, p.120-126, 2008.

DIAS, T.C.S; BABY, A.R; KANEKO, T.M.; VELASCO, M.V.R. Relaxing/straightening of Afro-ethnic hair: historical overview. J. Cosmet. Dermatol., Oxford, v.6, n.1, p.2-5, 2007.

DIAS, T.C.S.; LURI, J.; DARINI, A.P.; BABY, A.R.; KANEKO, T.M.; VELASCO, M.V.R. Avaliação de mechas de cabelo Afro-étnico alisadas quimicamente por tração de ruptura e perda protéica. Rev. Bras. Cienc. Farm., São Paulo, v.41, supl.2, p.102, 2005.

FEUGHELMAN, M. Morphology and properties of hair. In: JOHNSON, D.H., (Ed.). Hair and hair care. New York: Marcel Dekker, 1997. cap.1 e 2, p.1-32.

FREITAS, A.Z.; ZEZELL, D.M.; VIEIRA, N.D.; RIBEIRO, A.C.; GOMES A.S.L. Imaging carious human dental tissue with optical coherence tomography. J. Appl. Phys., New York, v.99, n.2, p.024906-024906-6, 2006.

FREITAS, A.Z.; BABY, A.R.; MATHOR, M.B.; VIEIRA JUNIOR, N.D.; BEDIN, V.; VELASCO, M.V.R. Tomografia por coerência óptica (OCT) aplicada à Cosmetologia: caracterização estrutural preliminar de fibras capilares. In: CONGRESSO BRASILEIRO DE COSMETOLOGIA, 22, São Paulo, 2008. Anais. São Paulo: Associação Brasileira de Cosmetologia, 2008. 1 CD-ROM.

GARCIA, M. L.; DIAZ, J. Combability measurements on human hair. J. Soc. Cosmet. Chem., New York, v.27, n.9, p.379-398, 1976.

GURDEN, S.P.; MONTEIRO, V.F.; LONGO, E.; FERREIRA, M.M.C. Quantitative analysis and classification of AFM images of human hair. J. Microsc., Oxford, v.215, n.1, p.13-23, 2004.

HUANG, D.; SWANSON, E.A.; LIN, C.P.; SCHUMAN, J.S.; STINSON, W.G.; CHANG, W.; HEE, M.R.; FLOTTE, T.; GREGORY, K.; PULIAFITO, C.A.; FUJIMOTO, J.G. Optical coherence tomography. Science, Washington, v.254, n.5035, p.1178-1181, 1991.
ISHII, M. Objective and instrumental methods for evaluation of hair care product efficacy and substantiation claims. In: JOHNSON, D.H., (Ed.). Hair and hair care. New York: Marcel Dekker, 1997. cap.10, p.261-295.

JUEZ, J.L.; GIMIER, L. Ciencia cosmética. 2.ed. Madrid: Soc. Espanhola de Quim. Cosmet., 1983. p.98-119.

KAPLIN, I.J.; SCHWAN, A.; ZAHN, H. Effects of cosmetic treatments on the ultrastructure of hair. Cosmet. Toiletries, Carol Stream, v.97, n.8, p.22-25, 1982.

KOLAR, G.; MILLER, A. Hair straighteners. In: BALSAM, M.S.; SAGARIN, E. Cosmetics science and technology. 2.ed. New York: Interscience, 1972. cap.22, p.150-277.

LONGO, V.M.; MONTEIRO, V.F.; PINHEIRO, A.S.; TERCI, D.; VASCONCELOS, J.S.; PASKOCIMAS, C.A.; LEITE, E.R.; LONGO, E.; VARELA, J.A. Charge density alterations in human hair fibers: an investigation using electrostatic force microscopy. Int. J. Cosmet. Sci., Oxford, v.28, n.2, p.95-101, 2006.

OLIVEIRA, V. Modificadores estruturais do cabelo, Cosmet. Toiletries, Ed. Port., São Paulo, v.12, n.2, p.59-62, 2000.

PAULA, C.M.S.S. Alterações na ultra-estrutura do cabelo induzidas por cuidados diários e seus efeitos nas propriedades de cor. Campinas, 2001. 119p. [Tese de Doutorado. Instituto de Química. Universidade Estadual de Campinas].

POSTIAUX, S. Wet combing evaluation sensory evaluation of dry hair by triangular test. Woluwé: Dow Corning, 2000. p.1-12.

REIMER, B.; OLDINSKI, R.; GLOVER, D. An objective method for evaluating hair shine. Soap, Cosmet., Chem. Spec., Melville, v.10, n.71, p.25-32, 1995.

ROBBINS, C.R. Chemical and physical behavior of human hair. 3.ed. New York: Springer, 1994. 391p.

ROBBINS, C.R.; CRAWFORD, R.J. Cuticle damage and the tensile properties of human hair. J. Soc. Cosmet. Chem., New York, v.42, n.1, p.59-67, 1991.

RUETCH, S.B.; WEIGMANN, H.-D. Mechanism of tensile stress release in the keratin fiber cuticle: I. J Soc. Cosmet. Chem., New York, v.47, n.1, p.13-26, 1996. 
SCHLAKE, T. Determination of hair structure and shape. Semin. Cell Dev. Biol., London, v.18, n.2, p.267-273, 2007.

SCHUELLER, R.; ROMANOWSKI, P. Evaluating shine on hair. Cosmet. Toiletries, Carol Stream, v.116, n.12, p.4752, 2001.

SMITH, J.R. Use of atomic force microscopy for high-resolution non-invasive structural studies of human hair. $J$. Soc. Cosmet. Chem., New York, v.48, n.4, p.199-208, 1997.

STARCH, M.S. Screening Silicones for hair luster. Cosmet. Toiletries, Carol Stream, v.114, n.11, p.55-60, 1999.

SWIFT, J.A. Human hair cuticle: biologically conspired to the owner's advantage. Int. J. Cosmet. Sci., Oxford, v.50, n.1, p.23-47, 1999.

SYED, A.N.; KUHAJDA, A.; AYOUB, H.; AHMAD, K.; FRANK, E.M. Cabelo afro-americano vs. caucasiano: propriedades físicas. Cosmet. Toiletries, Ed. Port., São Paulo, v.8, n.3, p.55-59, 1996.

TAKADA, K.; YOKOHAMA, I.; CHIDA, K.; NODA, J. New measurement system for fault location in optical waveguide devices based on an interferometric technique. Appl. Opt., Washington, v.26, n.9, p.1603-1606, 1987.
TATE, J.M.; KAMATH, Y.K.; RUETSCH, B.; WEIGMANN, H.-D. Quantification and prevention of hair damage. J. Soc. Cosmet. Chem., New York, v.44, n.6, p.347-371, 1993.

WAGNER, R.C.C.; JOEKES, I. Hair protein removal by sodium dodecyl sulfate. Colloids Surf. B Biointerfaces, Amsterdam, v.41, n.1, p.7-14, 2007.

WAGNER, R.C.C.; KIYOHARA, P.K.; SILVEIRA, M.; JOEKES, I. Electron microscopic observations of human hair medulla. J. Microsc., Oxford, v.226, n.1, p.54-63, 2007.

WILKINSON, J.B.; MOORE, R.J. Cosmetologia de Harry. Madrid: Diaz de Santos, 1990. 1039p.

WOODRUFF, J. Aumento da resistência mecânica dos cabelos. Cosmet. Toiletries, Ed. Port., São Paulo, v.14, n.5, p.62-64, 2002.

YOUNGQUIST, R.C; CARR, S; DAVIES, D.E.N. Optical coherence-domain reflectometry: a new optical evaluation technique. Opt. Lett., New York, v.12, n.3, p.158-160, 1987.

Recebido para publicação em 18 de abril de 2008. Aceito para publicação em 16 de julho de 2008. 